\title{
Author Correction: Historical dynamics of landslide risk from population and forest-cover changes in the Kivu Rift
}

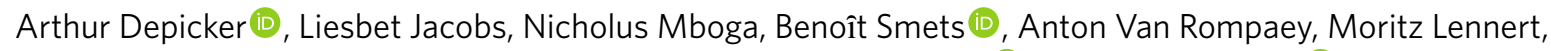
Eléonore Wolff, François Kervyn, Caroline Michellier, Olivier Dewitte (D) and Gerard Govers (B)

Correction to: Nature Sustainability https://doi.org/10.1038/s41893-021-00757-9, published online 19 August 2021.

In the version of this Article initially published, an error appeared in the caption to Fig. 4, where the descriptions for panels b and c were reversed. The caption has been corrected to read: "b, Landslide hazard trends when we assume there is no landslide response to deforestation in new forests. c, Landslide hazard trends in the Kivu Rift when we assume the landslide response to deforestation is the same for new and primary forests." The error has been corrected in the online version of the Article.

Published online: 22 September 2021

https://doi.org/10.1038/s41893-021-00788-2

(c) The Author(s), under exclusive licence to Springer Nature Limited 2021 